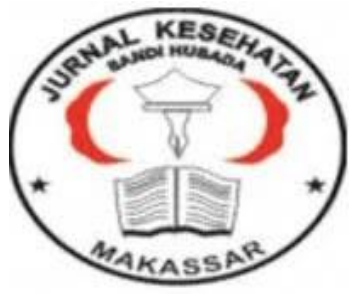

\author{
Jurnal Ilmiah Kesehatan Sandi Husada \\ hhttps://akper-sandikarsa.e-journal.id/JIKSH \\ Vol 9, No, 1, Juni 2020, pp; 62-71 \\ p-ISSN: 2354-6093 dan e-ISSN: 2654-4563 \\ DOI: $10.35816 /$ jiskh.v10i2.220
}

\title{
Konsumsi Ikan Asin dan Daging Asap dengan Kejadian Karsinoma Nasofaring
}

The Consumption of Salted Fish and Smoked Meats with the Incidence of Nasopharyngeal Carcinoma

\author{
Muslim Kasim ${ }^{1}$, Tan'im ${ }^{2}$, Upik Pebriyani ${ }^{3}$, Eva Aprillya ${ }^{4}$ \\ ${ }^{1}$ Bagian Departemen THT-KL, Rumah Sakit Bintang Amin Bandar Lampung \\ 2 Bagian Departemen THT-KL RSUD Alimuddin Umar \\ 3Departemen Anatomi, Pendidikan Kedokteran Universitas Malahayati \\ 4Program Studi Kedokteran Umum, Fakultas Kedokteran Universitas Malahayati
}

\section{Artikel history:}

Received; 14 Maret 2020

Revised; 15 Maret 2020

Accepted; 17 Maret 2020

\begin{abstract}
Abstrak
Latar Belakang: Faktor dominan timbulnya karsinoma nasofaring adalah dari Ras Mongoloid dengan kebiasaan mengkonsumsi ikan asin dan makanan yang diawetkan salah satunya daging asap. Tujuan : Untuk mengetahui hubungan antara konsumsi ikan asin dan daging asap dengan kejadian karsinoma nasofaring. Metode : Penelitian ini metode observasional analitik dan menggunakan pendekatan cross sectional. Sampel pada penelitian ini adalah seluruh pasien yang didiagnosis karsinoma nasofaring yang tercatat dalam Rekam yang sesuai kriteria inklusi berjumlah 52 orang. Teknik pengambilan sampel pada penelitian ini menggunakan Teknik total sampling. Analisis data menggunakan analisis univariat dan analisis bivariat menggunakan uji chi-square. Hasil : dari 52 responden diketahui distribusi frekuensi karakteristik pasien karsinoma nasofaring mayoritas berjenis kelamin laki-laki sebesar 64,4\%, mayoritas tertinggi pada kelompok usia 46-55 tahun sebesar 32,7\%, pekerjaan terbanyak adalah petani sebesar 32,7\%. Diketahui terdapat hubungan yang signifikan antara konsumsi ikan asin dengan kejadian karsinoma nasofaring (p:0,003) dan terdapat hubungan yang signifikan antara konsumsi daging asap dengan kejadian karsinoma nasofaring (p:0,002). Kesimpulan: Terdapat hubungan yang signifikan antara konsumsi ikan dan konsumsi daging asap dengan kejadian karsinoma nasofaring.
\end{abstract}

\begin{abstract}
Background: The dominant factor in the onset of nasopharyngeal carcinoma is that of the Mongoloid race with the habit of consuming salty fish and food preserved by one of them bacon. Purpose: To know the relationship between the consumption of salted fish and smoked meats with the incidence of nasopharyngeal carcinoma. Methode : This research method is observational analytic and uses a cross sectional approach. The samples in this study were all patients diagnosed with nasopharyngeal carcinoma
\end{abstract}


recorded which corresponds to the inclusion Criteria amounting to 52 persons. The sampling techniques in this study used the total sampling technique. Analysis of data using univariate analysis and bivariate analysis using chi-square test. Results: frequency distribution characteristic of the nasopharyngeal carcinoma patient majority of male gender at $64.4 \%$, the highest majority in the age group 46-55 years by $32.7 \%$, the most work is farmers of $32.7 \%$. There is a significant connection between the consumption of salted fish and the occurrence of nasopharyngeal carcinoma ( $p: 0.003$ ) and there is a significant link between the consumption of smoked meats and the incidence of nasopharyngeal carcinoma (p:0.003). Conclusion: There is a significant link between the consumption of fish and smoked meats with the incidence of nasopharyngeal carcinoma.

Keywords:

Ikan Asin;

Daging Asap;

Karsinom Nasofaring;
Coresponden author:

Email: evaaprillya13@gmail.com

artikel dengan akses terbuka dibawah lisensi CC BY -4.0

\section{Pendahuluan}

Karsinoma Nasofaring (KNF) adalah tumor ganas utama di nasofaring yang merupakam tumor ganas epitel nasofaring pada daerah endemis (Rahman et al., 2015). Faktor dominan timbulnya karsinoma nasofaring adalah dari Ras Mongoloid, sehingga masih sering terjadi pada penduduk Cina bagian selatan, Hongkong, Vietnam, Thailand, Malaysia, Singapura dan Indonesia. Sebagian besar masyarakat Indonesia termasuk ke dalam ras mongoloid dengan kebiasaan mengkonsumsi ikan asin. Ikan asin termasuk kedalam 9 bahan makanan pokok masyarakat Indonesia (Faiza et al., 2016).

Karsinoma Nasofaring lebih sering ditemukan pada laki-laki dengan perbandingan sekitar 2-3 kali lebih tinggi dibandingkan wanita, dengan frekuensi usia pasien KNF mulai meningkat setelah usia 30 tahun dengan puncak tertinggi saat usia 45-55 tahun (Rahman et al., 2015). Karsinoma nasofaring termasuk dalam lima besar tumor ganas dengan presentasi paling banyak diantara tumor ganas lainnya. Insiden karsinoma nasofaring hampir 60\% terjadi dari tumor di daerah kepala dan leher, kemudian 18\% diikuti oleh tumor ganas hidung dan sinus paranasal, laring $16 \%$,dan tumor ganas rongga mulut, tonsilhipofaring dalam presentasi rendah. Di Indonesia, karsinoma nasofaring merupakan urutan ke-4 setelah karsinoma payudara, karsinoma leher Rahim, dan karsinoma paru.

Terjadinya karsinoma nasofaring disebabkan oleh beberapa faktor diantaranya disebabkan oleh genetic, virus, kebiasaan gaya hidup, dan lingkungan (Bustam et al., 2018) Suku Jawa, Sunda dan Betawi merupakan jenis ras yang paling dominan untuk mengalami karsinoma nasofaring (Adham et al., 2012). Asap rokok, pajanan formaldehid dan konsumsi ikan asin termasuk kedalam faktor lingkungan penyebab karsinoma nasofaring (Yong et al., 2017). Faktor pencetus karsinoma nasofaring terdapat didalam ikan asin yang mengandung nitrosamine (Dhaneshor Sharma et al., 2011).Menurut data dari Rumah Sakit Hasan Sadikin Bandung didapatkan 60 kasus. Berdasarkan dari hasil penelitian konsumsi ikan asin $\geq 3$ kali perbulan memiliki resiko lebih tinggi sebesar 7,5 kali terkena karsinoma nasofaring (Rahman et al., 2015). 


\section{Metode}

Jenis pada penelitian ini adalah penelitian observasional analitik dan menggunakan pendekatan cross sectional yang bertujuan unutuk mengetahui hubungan antara konsumsi ikan asin dan daging asap dengan kejadian karsinoma nasofaring di RSUD Abdul Moeloek Bandar Lampung tahun 2020. Populasi pada penelitian ini adalah seluruh pasien yang didiagnosis karsinoma nasofaring yang tercatat dalam Rekam Medik yang sesuai kriteria inklusi berjumlah 52 responden. Pengumpulan data skunder dan primer melalui telpon dengan menggunakan teknik total sampling.

Kriteria inklusi pada penelitian ini adalah pasien karsinoma nasofaring dengan data rekam medik yang lengkap, terdapat no telpon pasien atau keluarga pasien pada catatan rekam medik, Pasien yang kooperatif saat melakukan wawancara. Kriteria eksklusi terdiri dari pasien yang sudah meninggal saat penelitian berlangsung, asien yang menolak untuk diwawancara serta alergi terhadap ikan asin dan daging asap. Variabel independent dalam penelitian ini adalah konsumsi ikan asin dan daging asap, variabel dependent dalam penelitian ini adalah karsinoma nasofaring. Pengolahan data menggunakan analisis univariat untuk mengatahui prevalensi variabel independen dan variabel dependen dan analisis bivariat mengguna chi-cquare.

\section{Hasil Dan Pembahasan}

\section{Hasil}

Tabel 1 Karakteristik Responden Berdasarkan Jenis Kelamin

\begin{tabular}{llcc}
\hline No & Jenis Kelamin & Frekuensi (n) & Persentase (\%) \\
\hline 1 & Laki-laki & 34 & 65,4 \\
2 & Perempuan & 18 & 34,7 \\
\hline & Total & $\mathbf{5 2}$ & $\mathbf{1 0 0}$
\end{tabular}

Berdasarkan tabel 1 didapatkan bahwa prevalensi jenis kelamin pasien karsinoma nasofaring lebih banyak terdapat pada laki-laki sebanyak $34(65,4 \%)$ responden.

\section{Tabel 2 Karakteristik Responden Berdasarkan Usia}

\begin{tabular}{llcc}
\hline No & Usia (tahun) & Frekuensi (n) & Persentase (\%) \\
\hline 1 & $\leq 25$ & 6 & 11,5 \\
2 & $26-35$ & 4 & 7,7 \\
3 & $36-45$ & 11 & 21,2 \\
4 & $46-55$ & 17 & 32,7 \\
5 & $56-65$ & 13 & 25,0 \\
6 & $\geq 66$ & 1 & 1,9 \\
\hline & Total & $\mathbf{5 2}$ & $\mathbf{1 0 0}$
\end{tabular}

Berdasarkan tabel diatas didapatkan bahwa prevalensi usia pasien karsinoma nasofaring di RSUD Abdul Moeloek paling tertinggi pada kelompok usia 46 - 55 tahun sebanyak 17 responden $(32,7 \%)$ responden.

Tabel 3 Karakteristik Responden Berdasarkan Pekerjaan

\begin{tabular}{llcc}
\hline No & Pekerjaan & Frekuensi (n) & Persentase (\%) \\
\hline 1 & Petani & 17 & 32,7 \\
2 & Wiraswasta & 16 & 30,8 \\
3 & IRT & 10 & 31,2 \\
4 & Pelajar/mahasiswa & 5 & 15,6 \\
5 & Pegawai Swasta & 2 & 6,2 \\
6 & PNS & 2 & 6,2 \\
\hline & Total & $\mathbf{5 2}$ & $\mathbf{1 0 0}$ \\
\hline
\end{tabular}

Muslim Kasim, etall, The Consumption of Salted Fish and Smoked Meats with the Incidence of Nasopharyngeal Carcinom, jiksh Vol.9 No.1 Juni 2020 
Berdasarkan tabel diatas didapatkan bahwa prevalensi terbanyak dengan pekerjaan petani sebanyak 17 (32,7\%) responden.

Tabel 5 Distribusi Frekuensi Kebiasaan Konsumsi Ikan Asin Pasien Karsinoma Nasofaring

\begin{tabular}{llcc}
\hline No & Kebiasaan Konsumsi Ikan Asin & Frekuensi (n) & Persentase (\%) \\
\hline 1 & $\begin{array}{l}\text { Suka/sering konsumsi ikan asin (> 3 kali } \\
\text { dalam sebulan) }\end{array}$ & 33 & 63,5 \\
2 & $\begin{array}{l}\text { Tidak suka atau jarang konsumsi ikan } \\
\text { asin (1-3 kali dalam sebulan) }\end{array}$ & 19 & 36,5
\end{tabular}

Total $\quad 52 \quad 100$

Hasil penelitian berdasarkan makan ikan asin pada pasien karsinoma nasofaring didapatkan bahwa prevalensi kebiasaan konsumsi ikan asin pasien karsinoma nasofaring lebih banyak daripada tidak mengkjonsumsi, sebanyak $33(63,5 \%)$ responden.

Tabel 6 Distribusi Frekuensi Kebiasaan Konsumsi Daging Asap Pasien Karsinoma Nasofaring

\begin{tabular}{llcc}
\hline No & Kebiasaan Konsumsi Daging Asap & Frekuensi (n) & Persentase (\%) \\
\hline 1 & $\begin{array}{l}\text { Suka/sering konsumsi daging asap (>3 } \\
\text { kali dalam sebulan) }\end{array}$ & 37 & 71,2 \\
2 & $\begin{array}{l}\text { Tidak suka atau jarang konsumsi daging } \\
\text { asap (1-3 kali dalam sebulan) }\end{array}$ & 15 & 28,8 \\
\hline Total & $\mathbf{5 2}$ & $\mathbf{1 0 0}$ \\
\hline
\end{tabular}

Hasil penelitian berdasarkan makan daging asap pada pasien karsinoma nasofaring didapatkan bahwa prevalensi kebiasaan konsumsi daging asap pasien karsinoma nasofaring lebih banyak dengan hasil sering konsumsi daging asap dari pada tidak suka/jarang konsumsi daging asap, sebanyak 37 (71,2\%) responden.

Tabel 7 Hubungan konsumsi ikan asin dengan kejadian karsinoma nasofaring

\begin{tabular}{|c|c|c|c|c|c|c|c|c|c|c|}
\hline \multirow{3}{*}{ No } & \multirow{3}{*}{ Konsumsi ikan asin } & \multicolumn{4}{|c|}{ Karsinoma nasofaring } & \multirow{2}{*}{\multicolumn{2}{|c|}{ Total }} & \multirow[t]{3}{*}{ OR } & \multirow{3}{*}{$\begin{array}{l}95 \% \mathrm{CI} \\
\text { (lower- } \\
\text { uppe) }\end{array}$} & \multirow{3}{*}{$\begin{array}{c}\text { p- } \\
\text { value }\end{array}$} \\
\hline & & \multicolumn{2}{|c|}{ PA (+) } & \multicolumn{2}{|c|}{ PA (-) } & & & & & \\
\hline & & $\mathbf{N}$ & $\%$ & $\mathbf{N}$ & $\%$ & $\mathbf{N}$ & $\%$ & & & \\
\hline 1 & $\begin{array}{l}\text { suka/sering konsumsi } \\
\text { ikan asin (> } 3 \text { kali dalam } \\
\text { sebulan) }\end{array}$ & 30 & $\begin{array}{c}90, \\
0\end{array}$ & 3 & 9,1 & 33 & 100 & 4,2 & $\begin{array}{l}1,08- \\
16,24\end{array}$ & 0,003 \\
\hline 2 & $\begin{array}{l}\text { tidak suka atau jarang } \\
\text { konsumsi ikan asin (1-3 } \\
\text { kali dalam sebulan) }\end{array}$ & 10 & $\begin{array}{c}52, \\
6\end{array}$ & 9 & 47,4 & 19 & 100 & & & \\
\hline & Jumlah & 40 & & 12 & & 52 & 100 & & & \\
\hline
\end{tabular}

Berdasarkan hasil penelitian sesuai tabel diatas menunjukkan hasil uji statistik dengan uji chi square didapatkan $p$ value : $0,038(\alpha<0,05)$ artinya terdapat hubungan yang signifikan antara konsumsi ikan asin dengan kejadian karsinoma nasofaring.

Tabel 8 Hubungan konsumsi daging asap dengan kejadian karsinoma nasofaring di RSUD Abdul Moeloek Bandar Lampung

\begin{tabular}{|c|c|c|c|c|c|c|c|c|c|c|}
\hline \multirow{3}{*}{ No } & \multirow{3}{*}{ Konsumsi daging asap } & \multicolumn{4}{|c|}{ Karsinoma nasofaring } & \multirow{2}{*}{\multicolumn{2}{|c|}{ Total }} & \multirow[t]{3}{*}{ OR } & \multirow{3}{*}{$\begin{array}{c}95 \% \\
\text { CI } \\
\text { (lower } \\
\text {-uppe) }\end{array}$} & \multirow{3}{*}{$\begin{array}{c}\text { p- } \\
\text { value }\end{array}$} \\
\hline & & \multicolumn{2}{|c|}{ PA (+) } & \multicolumn{2}{|c|}{ PA (-) } & & & & & \\
\hline & & $\mathbf{N}$ & $\%$ & $\mathbf{N}$ & $\%$ & $\mathbf{N}$ & $\%$ & & & \\
\hline 1 & \begin{tabular}{ll} 
suka/sering & \multicolumn{2}{c}{ konsumsi } \\
daging asap $>3$ kali
\end{tabular} & 33 & $\begin{array}{c}89, \\
2\end{array}$ & 4 & 10,8 & 37 & 100 & 4,7 & $\begin{array}{l}1,16- \\
19,02\end{array}$ & 0,002 \\
\hline
\end{tabular}

Muslim Kasim, etall, The Consumption of Salted Fish and Smoked Meats with the Incidence of Nasopharyngeal Carcinom, jiksh Vol.9 No.1 Juni 2020 


\begin{tabular}{llllllll}
\hline \multicolumn{2}{l}{ dalam sebulan) } & & & & & \\
tidak suka atau jarang & 7 & 46, & 8 & 53,3 & 15 & 100 \\
konsumsi daging (1-3 & & 7 & & & & \\
kali dalam sebulan) & & & & & & \\
\hline Jumlah & 40 & & 52 & \\
\hline
\end{tabular}

Hasil uji statistik dengan uji chi square didapatkan $p$ value : 0,002 $(\alpha<0,05)$ artinya terdapat hubungan yang signifikan antara konsumsi daging asap dengan kejadian karsinoma nasofaring.

\section{Pembahasan}

\section{Jenis Kelamin}

Hasil penelitian menunjukkan bahwa karakteristik sampel berdasarkan jenis kelamin didapatkan bahwa jumlah responden laki-laki sebanyak 34 (65,4\%) lebih besar dibandingkan responden perempuan sebanyak 18 (34,7\%) responden, hal ini sesuai dengan teori yang menyatakan bahwa secara umum, karsinoma nasofaring menempati peringkat kelima sebagai penyebab kematian tertinggi di Indonesia dibanding kanker tubuh lain. Insiden karsinoma nasofaring pada laki-laki sekitar 2-3 kali lebih tinggi dibandingkan dengan wanita (Rahman et al., 2015).Berbagai studi melaporkan bahwa KNF lebih sering didapatkan pada laki-laki dibanding perempuan, dengan perbandingan 2:1 (Adham et al., 2012).

Penelitian sejalan dengan penelitian Zhang dkk (2015) di China menyatakan bahwa karsinoma nasofaring terbanyak terjadi pada laki-laki dari pada wanita dimana dari 2.151 responden sebanyak 1,494 berjenis kelamin laki-laki dan sebanyak 657 berjenis kelamin perempuan (Zhang et al., 2015). Hasil serupa dengan penelitian Dawolo A.P (2017) tentang prevalensi karsinoma nasofaring di RSUP Dr. Mohammad Hoesin Palembang Tahun 2014-2015 menunjukkan bahwa dari 110 responden responden sebesar 72,73\% berjenis kelamin laki-laki. Hal tersebut terjadi karena gaya hidup laki-laki berbeda dengan perempuan seperti kebiasaan merokok dimana jumlah perokok pada laki-laki lebih tinggi daripada perempuan. Selain itu, Laki-laki juga memiliki pekerjaan yang cenderung mengakibakan KNF dikarenakan terpaparnya bahan kimia (Dawolo et al., 2019).

\section{Usia}

Hasil penelitian berdasarkan karakteristik usia dari 52 responden didapatkan bahwa prevalensi usia pasien karsinoma nasofaring di RSUD Abdul Moeloek paling tertinggi pada kelompok usia 46 - 55 tahun sebanyak 17 responden $(32,7 \%)$ dan paling rendah pada kelompok usia $\geq 66$ tahun. Hal ini sesuai dengan teori yang menyatakan bahwa keganasan nasofaring menyerang pada usia sekitar 40 tahun dikarenakan sistem imun menurun pada usia tersebut, sehingga antigen virus EBV tidak dapat diserang oleh sistem imun. Hasil Penelitian ini hampir sama dengan hasil penelitian yang dilakukan di tempat lain. Pada penelitian di Amerika dan Eropa, dan daerah endemik ditemukan peningkatan insidensi KNF pada umur 20 tahun dan puncaknya pada 40-50 tahun, sedangkan didaerah yang beresiko rendah ditemukan peningkatan insidensi KNF pada umur 15 tahun dan puncaknya pada umur 50-60 tahun. Hal tersebut terjadi karena faktor resiko seperti kebiasaan merokok dan konsumsi ikan asin sejak usia dini, sehingga KNF dapat muncul ketika seseorang telah mencapai usia produktif, karena mulai dari paparan pertama bahan karsinogen sampai timbulnya kanker memerlukan waktu yang lama (Dawolo et al., 2019). Berdasarkan distribusi tipe histopatologis menurut usia, tipe undifferentiated carcinoma (WHO tipe III) memiliki angka kejadian terbanyak pada rentang usia 45-54 tahun, yaitu 41 
$(73,2 \%)$ kasus, diikuti tipe non keratinizing squamous cell carcinoma (WHO tipe II) terdapat pada rentang usia 35-44 tahun, yaitu 16 (33,3\%) kasus dan tipe keratinizing squamous cell carcinoma (WHO tipe I) terdapat pada rentang usia 25-54 tahun (A, 2016). Hasil sejalan dengan penelitian Dawolo A.P dkk (2017) menunjukkan paling tinggi sebanyak 30,91\% terdapat pada kelompok usia 46-55 tahun peningkatan insidensi KNF pada umur 20 tahun dan puncaknya pada 40-50 tahun, sedangkan di daerah yang beresiko rendah ditemukan peningkatan insidensi KNF pada umur 15 tahun dan puncaknya pada umur 50-60 tahun. Hal tersebut terjadi karena faktor resiko seperti kebiasaan merokok dan konsumsi ikan asin sejak usia dini, sehingga KNF dapat muncul ketika seseorang telah mencapai usia produktif, karena mulai dari paparan pertama bahan karsinogen sampai timbulnya kanker memerlukan waktu yang lama (Dawolo et al., 2019).

\section{Pekerjaan}

Hasil penelitian berdasarkan prevalensi pekerjaan pasien karsinoma nasofaring mayoritas dengan pekerjaan petani sebanyak $17(32,7 \%)$ responden dan paling sedikit pegawai swasta dan PNS masing-masing sebanyak $2(6,2 \%)$ responden. Penelitian sejalan dengan penelitian Diniati A (2017) yang menyatakan bahwa prevalensi karsinoma nasofaring tertingga pada responden dengan pekerjaan petani $16,1 \%(\mathrm{~A}, 2016)$

\section{Diketahui distribusi frekuensi pasien karsinoma nasofaring di RSUD Abdul Moeloek Bandar Lampung tahun 2020}

Hasil penelitian berdasarkan pemeriksaan PA pasien karsinoma nasofaring mayoritas dengan hasil PA (+) daripada hasil PA (-) sebanyak $40(76,9 \%)$ responden dengan hasil PA $(+)$ dan $12(23,1 \%)$ responden dengan hasil PA (-). Hal ini disebabkan karena distribusi keganasan nasofaring menurut tipe histopatologis berdasarkan kriteria WHO, angka terbanyak terdapat pada undifferentiated carcinoma (WHO tipe III), yaitu 136 kasus (68,3\%). Kemudian diikuti tipe non keratinizing squamous cell carcinoma (WHO tipe II), yaitu 60 kasus $(30,2 \%)$ dan tipe keratinizing squamous cell carcinoma (WHO tipe I) memiliki angka terendah, yaitu 3 kasus $(1,5 \%)$ pada rumah sakit di Kota Pekanbaru. Kebiasaan mengkonsumsi ikan asin sejak usia dini meningkatkan risiko terjadinya keganasan nasofaring. Hal ini didukung oleh teori bahwa tipe undifferentiated carcinoma (WHO tipe III) berkaitan dengan makanan yang diawetkan dan infeksi EBV (Adham et al., 2012).

Karsinoma nasofaring (KNF) adalah Tumor yang berasal dari sel-sel epitel yang melapisi permukaan nasofaring. Tumor ini umumnya berasal dari fossa rosenmuller pada nasofaring yang merupakan daerah transisional dimana epitel kuboid berubah menjadi epitel skuamosa. Karsinoma nasofaring merupakan kanker yang mempunyai keunikan dan berbeda dari tumor ganas di daerah kepala dan leher lainnya dalam hal epidemiologi, spektrum gambaran histopatologi, karakteristik klinik dan sifat biologi. Hasil penelitian sejalan dengan penelitian Diniati A (2017), bahwa mayoritas responden menunjukkan hasil PA karsinoma nasofaring (+) (A, 2016). Hasil serupa dengan penelitian Dawolo A.P dkk (2017) menunjukkan responden mayoritas dengan gambaran PA (+) (Dawolo et al., 2019).

\section{Diketahui distribusi frekuensi konsumsi ikan asin pasien karsinoma nasofaring di RSUD Abdul Moeloek Bandar Lampung tahun 2020}

Hasil penelitian menunjukkan bahwa bahwa mayoritas pasien karsinoma nasofaring lebih banyak dengan hasil sering konsumsi ikan asin > 3 kali dalam sebulan sebanyak 33 $(63,5 \%)$ responden dan 19 (36,5\%) responden dengan hasil tidak suka/jarang konsumsi ikan asin. Hal ini disebabkan karena Konsumsi ikan asin merupakan salah satu penyebab Muslim Kasim, etall, The Consumption of Salted Fish and Smoked Meats with the Incidence of Nasopharyngeal Carcinom, jiksh Vol.9 No.1 Juni 2020 
karsinoma nasofaring yang sering dilaporkan.Beberapa penelitian epidemiologik dan laboratorium menyokong hipotesa yang menyebutkan bahwa konsumsi dini ikan asin menyebabkan KNF di Cina Selatan dan Hongkong. Suatu studi kasus kontrol menunjukkan bahwa hanya konsumsi ikan asin yang sering sebelum usia 10 tahun yang berhubungan dengan peningkatan resiko terjadinya KNF. Hasil serupa dengan penelitian Diniati A dkk (2016) di Riau menunjukkan bahwa mayoritas responden KNF sering/suka mengkonsumsi ikan asin hal ini kemungkinan disebabkan kebiasaan mengkonsumsi makanan yang diawetkan, seperti ikan asin atau ikan salai maupun makanan kaleng serta pengaruh paparan zat karsinogen pada sebagian mata pencarian warga Riau. Berdasarkan literatur, paparan bahan pengawet formaldehyde yang didapatkan pada makanan yang di awetkan merupakan zat karsinogen yang sering mencapai daerah nasofaring melalui inhalasi dan oral (A, 2016).

Namun hasil berbeda dengan penelitian Putera I dkk (2017) yang menyatakan bahwa mayoritas pasien KNF tidak suka/hanya mengkonsumsi ikan asin $<3$ kali dalam sebulan dengan hasil sebanyak 327 tidak mengkonsumsi ikan asin dan 375 mengkonsumsi ikan asin (Putera et al., 2015). Berdasarkan hasil penelitian yang dilakukan dan berbagai literature kebiasaan mengkonsumsi ikan asin $>3$ kali dalam sebulan meningkatkan risiko karsinoma nasofaring hal ini disebabkan karena Ikan asin mengandung zat karsinogenik yaitu nitrosamin yang memiliki metabolik aktif $\mathrm{CYP}_{2} \mathrm{E}_{1}$ yang dapat meningkatkan risiko karsinoma nasofaring (Yong et al., 2017).

\section{Diketahui distribusi frekuensi konsumsi daging asap pasien karsinoma nasofaring di RSUD Abdul Moeloek Bandar Lampung tahun 2020}

Hasil penelitian sejalan berdasarkan teori tersebut, mayoritas pasien karsinoma nasofaring mengkonsumsi daging asap > 3 kali sebanyak $37(71,2 \%)$ responden dan 15 $(28,8 \%)$ responden dengan hasil tidak suka/jarang konsumsi daging asap. Daging asap merupakan makanan berpengawet yang mengandung formaldehid. International Agency for Research on Cancer (IARC) memasukkan formaldehid menjadi kategori grup I sebagai bahan yang bersifat karsinogen dalam tubuh manusia (Lin et al., 2015). Bahan makanan yang terpapar oleh bahan zat aditif seperti pengawet nitrit dan zat warna azo berkaitan dengan induksi proses karsinogenesis. Nitrit dan nitrat yang digunakan dalam daging akan berikatan dengan myoglobin dan menghambat pembentukan eksotoksin botulinum, namun sangat karsinogenik (Sudiono \& Hassan, 2013).

Penelitian serupa dengan Diniati A dkk (2016) di kepulauan Riau, mayoritas penduduk yang sering mengkonsumsi makanan siap saji termasuk daging asap terkena KNF, hal ini disebabkan karena kandungan formaldehyde dalam bahan makanan yang diawetkan. Formaldehyde yang telah mencapai area nasofaring tersebut akan bermetabolisme menjadi bersifat reaktif dalam ikatan dengan DNA (ultimate-carcinogen), lalu terjadi mutasi genetik dan menyebabkan terjadinya keganasan nasofaring. Zat karsinogen lainnya seperti peptisida, dll juga berpengaruh terhadap terjadinya keganasan nasofaring (A, 2016). Namun hasil berbeda dengan penelitian Putera I dkk (2017) yang menyatakan bahwa mayoritas pasien KNF tidak suka/hanya mengkonsumsi daging asap/makanan siap saji $<3$ kali dalam sebulan karena masih banyak faktor yang menyebabkan kejadian KNF seperti merokok (Putera et al., 2015)

Hubungan konsumsi ikan asin dengan kejadian karsinoma nasofaring di RSUD Abdul Moeloek Bandar Lampung tahun 2020 
Berdasarkan hasil penelitian menunjukkan bahwa dari 53 responden terdapat 33 responden dengan kebiasaan suka/sering konsumsi ikan asin $>3$ kali dalam sebulan dimana hasil PA (+) sebanyak 30 responden (90,0\%) dan hasil PA (-) sebanyak 3 responden $(9,1 \%)$ serta dari 19 responden tidak suka/jarang mengkonsumsi ikan asin sebanyak 10 responden $(52,6 \%)$ dengan hasil PA $(+)$ dan 9 responden $(47,4 \%)$ dengan hasil PA (-). Hasil uji statistik dengan uji chi square didapatkan $p$ value : $0,038(\alpha<0,05)$ terdapat hubungan yang signifikan antara konsumsi ikan asin dengan kejadian karsinoma nasofaring di RSUD Dr. H. Abdul Moeloek tahun 2020, dimana nilai OR didapatkan 4,2 dengan confidence interval (CI) 95\% sebesar (1,08-16,24), artinya responden yang dengan kebiasaan makan ikan asin sering atau > 3 kali dalam sebulan meningkatkan 4,2 kali risiko terjadinya karsinoma nasofaring. Dimana nilai OR diantara nilai CI dengan selisih OR dengan Upper 16,2 dan selisih OR dengan Lower 1,0 yang menunjukkan rentan yang cukup tinggi sehingga hal ini menunjukkan bahwa rentang tingkat kepercayaan rendah, peneliti berpendapat hal ini kemungkinan disebabkan karena peneliti hanya menanyakan suka atau tidak sukanya mengkonsumsi ikan asin, tanpa meneliti apakah ikan asin tersebut mengandung formalin atau tidak dan peneliti juga tidak menanyakan kebiasaan merokok pada pasien.

Penelitian serupa hasil penelitian di Guangdong menunjukkan 6,7\% kelompok case mengonsumsi ikan asin $\geq 3$ kali perbulan sedangkan 3,8\% pada kelompok control mengonsumsi ikan asin $\leq 3$ kali perbulan. Sehingga dapat disimpulkan kebiasaan mengonsumsi ikan asin sebanyak $\geq 3$ kali perbulan dapat meningkatkan risiko KNF. Hal ini disebabkan karena Ikan asin dapat meningkatkan risiko KNF karena mengandung nitrosamin yang merupakan zat karsinogenik. Nitrosamin dapat mengaktifkan virus EBV yang mengekspresikan salah satu protein yaitu LMP1. Protein ini dapat menyebabkan mutasi DNA akibatnya terjadi perubahan gen regulator apoptosis sehingga apoptosis menjadi terganggu. Hal ini menyebabkan pertumbuhan sel secara terus menerus sehingga dapat timbulnya KNF. Nitrosamin dapat mengaktifkan virus EBV yang mengekspresikan salah satu protein yaitu LMP1. Protein ini dapat menyebabkan mutasi DNA akibatnya terjadi perubahan gen regulator apoptosis sehingga apoptosis menjadi terganggu. Hal ini menyebabkan pertumbuhan sel secara terus menerus sehingga dapat timbulnya KNF (Lau et al., 2013).

Namun hasil berbeda dengan penelitian yang dilakukan Putera I dkk (2015) China Selatan menunjukkan bahwa tidak ditemukan hubungan yang konsisten antara konsumsi ikan asin dengan KNF. Terdapat tiga penelitian yang menunjukkan hubungan antara konsumsi ikan asin dan KNF dan ketiga penelitian tersebut dilakukan pada populasi China Selatan yang memang memiliki insidens KNF yang sangat tinggi dan terkait dengan jenis ikan asin Chineese-style yang dikonsumsi (Lau et al., 2013).

\section{Hubungan konsumsi daging asap dengan kejadian karsinoma nasofaring di RSUD Abdul Moeloek Bandar Lampung tahun 2020}

Berdasarkan hasil penelitian dari 52 responden pasien karsinoma nasofaring menunjukkan bahwa 37 responden dengan kebiasaan suka/sering konsumsi daging asap $>3$ kali dalam sebulan dimana hasil PA (+) sebanyak 33 responden $(89,2 \%)$ dan hasil PA () sebanyak 4 responden $(10,8 \%)$ serta dari 15 responden tidak suka/jarang mengkonsumsi daging asap sebanyak 7 responden (46,7\%) dengan hasil PA $(+)$ dan 8 responden $(53,3 \%)$ dengan hasil PA (-). Hasil uji statistik dengan uji chi square didapatkan $p$ value : 0,002 $(\alpha<0,05)$ yang artinya Ha di terima sehingga dapat disimpulkan terdapat hubungan yang signifikan antara konsumsi daging asap dengan kejadian karsinoma nasofaring di RSUD Dr. H. Abdul Moeloek tahun 2020, dimana nilai OR didapatkan 4,7 dengan confidence interval (CI) 95\% sebesar (1,16-19,02), artinya responden yang dengan

Muslim Kasim, etall, The Consumption of Salted Fish and Smoked Meats with the Incidence of Nasopharyngeal Carcinom, jiksh Vol.9 No.1 Juni 2020 
kebiasaan makan ikan asin sering atau $>3$ kali dalam sebulan meningkatkan 4,7 kali risiko terjadinya karsinoma nasofaring. Dimana nilai OR diantara nilai CI dengan selisih OR dengan Upper 19,0 dan selisih OR dengan Lower 1,1 yang menunjukkan rentan yang cukup tinggi sehingga hal ini menunjukkan bahwa rentang tingkat kepercayaan rendah. Hal ini kemungkinan disebabkan masih banyaknya kesalahan persepsi daging asap pada masing-masing responden serta masih banyak yang tidak mengetahui jenis daging asap.

Penelitian sejalan dengan penelitian Lau dkk (2013) yang menyatakan bahwa terdapat hubungan konsumsi daging asap/kalengan dengan kejadian KNF, banyaknya penduduk di cina yang mengkonsumsi daging asap dan kalengan sehingga meningkatkan risiko terjadinya KNF (Lau et al., 2013). Hal ini disebabkan menurut pernyataan International Agency for Research on Cancer (IARC) memberikan kategori grup I pada formaldehid sebagai bahan yang bersifat karsinogen dalam tubuh manusia. IARCH mengevaluasi pajanan formaldehid sebagai penyebab kematian akibat KNF. Proses pembakaran ikan/daging asap akan menghasilkan gas pembakaran berupa formaldehid yang dapat memberikan efek pengawetan dari ikan/daging asap tersebut. Formaldehid dimetabolisme oleh enzim-enzim tubuh menajadi ultimate-carcinogen (bersifat reaktif dalam ikatan dengan DNA) dan akan menyebabkan mutasi genetik yang menimbulkan KNF (Coggon et al., 2014).

\section{Simpulan Dan Saran}

Berdasarkan hasil penelitian mengenai hubungan kebiasaan konsumsi ikan asin dan daging asap dengan kejadian karsinoma nasofaring di RSUD Abdul Moeloek Bandar Lampung tahun 2020 dapat diambil kesimpulan sebagai berikut:

1. Diketahui distribusi frekuensi karakteristik pasien karsinoma nasofaring mayoritas berjenis kelamin laki-laki sebesar 64,4\%, mayoritas tertinggi pada kelompok usia 4655 tahun sebesar 32,7\% dengan pekerjaan terbanyak adalah petani sebesar 32,7\%.

2. Diketahui distribusi frekuensi pasien karsinoma nasofaring mayoritas dengan hasil PA (+) sebanyak $76,9 \%$

3. Diketahui distribusi frekuensi konsumsi ikan asin pasien karsinoma nasofaring mayoritas sering mengkonsumsi ikan asin $>3$ kali perbulan sebanyak 63,5\%.

4. Diketahui distribusi frekuensi konsumsi daging asap pasien karsinoma nasofaring mayoritas sering mengkonsumsi daging asap $>3$ kali perbulan sebanyak $71,2 \%$

5. Terdapat hubungan yang signifikan antara konsumsi ikan asin dengan kejadian karsinoma nasofaring (p.value 0,003: OR : 4,2)

6. Terdapat hubungan yang signifikan antara konsumsi daging asap dengan kejadian karsinoma nasofaring (p.value 0,002: OR : 4,7)

Hasil penelitian ini dapat digunakan sebagai informasi atau penyuluhan mengenai pembatsan dalam menkonsumsi ikan asin/daging asap serta diharapkan dapat digunakan sebagai sumber informasi supaya masyarakat lebih selektif dalam memilih makanan khususnya ikan asin/daging asap agar terhidar dari konsumsi ikan asin yang mengandung formalin. 


\section{Daftar Rujukan}

A, D. (2016). Distribusi keganasan nasofaring berdasarkan pemeriksaan histopatologi pada rumah sakit di kota pekanbaru tahun 2009-2013. Jom Fk, 3(1), 1-18.

Adham, M., Kurniawan, A. N., Muhtadi, A. I., Roezin, A., Hermani, B., Gondhowiardjo, S., Bing Tan, I., \& Middeldorp, J. M. (2012). Nasopharyngeal carcinoma in indonesia: Epidemiology, incidence, signs, and symptoms at presentation. Chinese Journal of Cancer, 31(4), 185-196. https://doi.org/10.5732/cjc.011.10328

Bustam, F. P., Berawi, K. N., Wahyudo, R., Kedokteran, F., Lampung, U., Fisiologi, B., Kedokteran, F., \& Lampung, U. (2018). Konsumsi ikan asin sebagai faktor resiko pada pasien karsinoma nasofaring. Medula, 8(1), 1-6.

Coggon, D., Ntani, G., Harris, E. C., \& Palmer, K. T. (2014). Upper airway cancer, Myeloid Leukemia, and other cancers in a cohort of British Chemical workers exposed to formaldehyde. American Journal of Epidemiology, 179(11), 1301-1311. https://doi.org/10.1093/aje/kwu049

Dawolo, A. P., Utama, D. S., \& Kasim, B. I. (2019). Profil Klinis Karsinoma Nasofaring di Departemen THTKL RSUP Dr. Mohammad Hoesin Palembang Tahun 2014-2015. Majalah Kedokteran Sriwijaya, 49(1), 1-9. https://doi.org/10.32539/mks.v49i1.8318

Dhaneshor Sharma, T., Tomcha Singh, T., Laishram, R. S., Durlav Chandra Sharma, L., Sunita, A. K., \& Tiameren Imchen, L. (2011). Nasopharyngeal carcinoma - A clinicopathological study in a regional cancer centre of northeastern India. Asian Pacific Journal of Cancer Prevention, 12(6), 1583-1587.

Faiza, S., Rahman, S., \& Asri, A. A. (2016). Karakteristik Klinis dan Patologis Karsinoma Nasofaring di Bagian THT-KL RSUP Dr.M.Djamil Padang. Jurnal Kesehatan Andalas, 5(1), 90-96. http://jurnal.fk.unand.ac.id/index.php/jka/article/view/450/378

Lau, H. Y., Leung, C. M., Chan, Y. H., Lee, A. W. in. M., Kwong, D. L. a. W., Lung, M. L. i., \& Lam, T. H. (2013). Secular trends of salted fish consumption and nasopharyngeal carcinoma: a multi-jurisdiction ecological study in 8 regions from 3 continents. BMC Cancer, 13, 298. https://doi.org/10.1186/1471-2407-13-298

Putera, I., Ramadhan, M. G., Anindya, S., Sutanto, N. R., Kurniawan, A., Hosea, F. N., \& Safitri, E. D. (2015). Relationship Between Salted Fish Consumption and Nasopharyngeal Carcinoma: An Evidence-based Case Report. Acta Medica Indonesiana, 47(1), 7277.

Rahman, S., Budiman, B. J., \& Subroto, H. (2015). Faktor Risiko Non Viral pada Karsinoma Nasofaring. Jurnal Kesehatan Andalas, 4(3), 988-995.

Sudiono, J., \& Hassan, I. (2013). DNA Epstein-Barr virus (EBV) sebagai biomaker diagnosis karsinoma nasofaring. Dental Journal (Majalah Kedokteran Gigi), 46(3), 140. https://doi.org/10.20473/j.djmkg.v46.i3.p140-147

Yong, S. K., Ha, T. C., Yeo, M. C. R., Gaborieau, V., McKay, J. D., \& Wee, J. (2017). Associations of lifestyle and diet with the risk of nasopharyngeal carcinoma in Singapore: A case-control study. Chinese Journal of Cancer, 36(1), 3-10. https://doi.org/10.1186/s40880-016-0174-3

Zhang, L. F., Li, Y. H., Xie, S. H., Ling, W., Chen, S. H., Liu, Q., Huang, Q. H., \& Cao, S. M. (2015). Incidence trend of nasopharyngeal carcinoma from 1987 to 2011 in sihui county, guangdong province, south china: An age-period-cohort analysis. Chinese Journal of Cancer, 34(8), 1-8. https://doi.org/10.1186/s40880-015-0018-6 